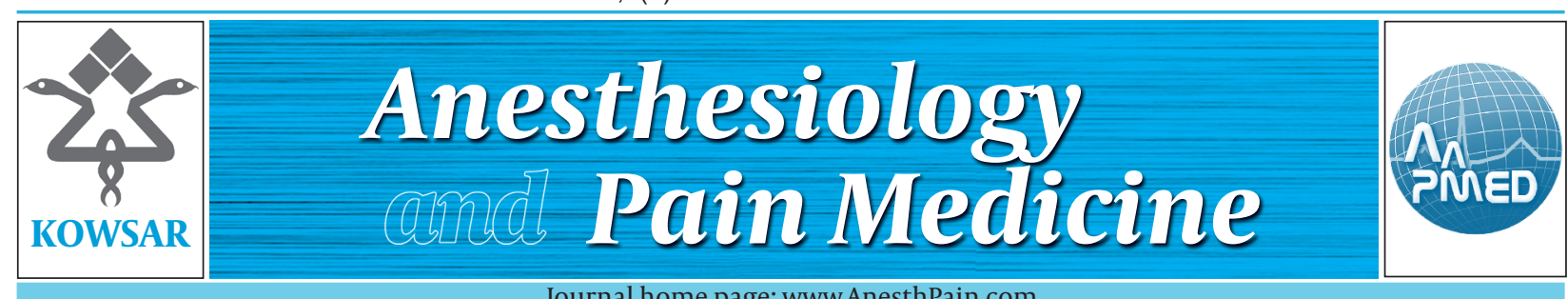

\title{
Role of Depression After Lumbar Disc Surgery
}

\author{
Lumir Hrabalek ${ }^{1^{*}}$ \\ ${ }^{1}$ Department of Neurosurgery, Faculty of Medicine and Dentistry, Palacky University and University Hospital Olomouc, Olomouc, Czech Republic
}

\section{A R T I C L E I N F O}

Article Type:

Letter to Editor

Article history:

Received: 05 Aug 2011

Revised: 07 Aug 2011

Accepted: 12 Aug 2011

\section{Keywords:}

Depression

Low-back pain

Discectomy

\section{Dear Editor,}

Evidently disc surgery patients are at higher risk of suffering from depression and anxiety than the general population (1). The authors have concluded that the depression and disability scores of patients with chronic herniated discs before lumbar discectomy significantly decreased after surgery (2). It has long been known that patients with psychological comorbidities often incur long-term disability from low-back pain $(3,4)$. Patients with disc herniation and more depressive symptoms were less likely to achieve clinically significant improvements in disability and pain after lumbar discestomy. Additionally, it may be valuable to assess patients for depression and somatization even after they have failed to benefit from discectomy (1). Somatization is a psychiatric diagnosis used to describe patients who chronically and persistently complain of pain without an identifiable physical origin (5). Hence, patients with depressive symptoms may benefit from preoperative psychological treatment with the aims of improving their outcomes. Psychological assess-

\footnotetext{
* Corresponding author: Lumir Hrabalek, Department of Neurosurgery, Faculty of Medicine and Dentistry, Palacky University and University Hospital Olomouc, Olomouc, Czech Republic, Tel: +420-732168812, Fax: +420588442539,E-mail: lumir. hrabalek@seznam.cz

DOI:10.5812/kowsar.22287523.2019

Copyright $\odot 2011$, ISRAPM, Published by Kowsar Corp.
}

- Please cite this paper as:

Hrabalek L, Role of Depression After Lumbar Disc Surgery. Anesth Pain. 2011;1(2):102.

DOI: 10.5812/kowsar.22287523.2019

Copyright $\odot 2011$, ISRAPM, Published by Kowsar Corp.

ment and assistance from menthal health professionals should be considered even during the hospital stay and rehabilitation period, depending on local feasibility (1). In conclusion, these patients may benefit from cognitive behavioral therapy or antidepressants prior to and after lumbar discectomy.

\section{Financial Disclosure}

None declared.

\section{References}

1. Zieger M, Schwarz R, Konig HH, Harter M, Riedel-Heller SG. Depression and anxiety in patients undergoing herniated disc surgery: relevant but underresearched - a systematic review. Cen Eur Neurosurg. 2010;71(1):26-34.

2. Farzanegan G, Alghasi M, Safari S, Ahmadi SA. Effects of lumbar discectomy on disability and depression in patients with chronic low back pain. Anesth Pain. 2011;1(1):20-4.

3. Turner JA, Robinson J, McCreary CP. Chronic low back pain: predicting response to nonsurgical treatment. Arch Phys Med Rehabil.1983;64(11):560-3.

4. Waddell G, Main CJ, Morris EW, Di Paola M, Gray IC. Chronic lowback pain, psychologic distress, and illness behavior. Spine (Phila Pa 1976). 1984;9(2):209-13.

5. Allen LA, Woolfolk RL, Escobar JI, Gara MA, Hamer RM. Cognitivebehavioral therapy for somatization disorder: a randomized controlled trial. Arch Intern Med. 2006;166(14):1512-8. 